\title{
LA CONFIGURACIÓN HISTÓRICA DE LAS ÉLITES DE HONDURAS ANTE EL GOLPE DE ESTADO DEL 2009
}

\author{
THE HISTORICAL TRAJECTORY OF HONDURAS'S \\ ELITES BEFORE THE COUP D'ETAT OF 2009
}

Darío A. Euraque

Recibido: 08/01/2019 - Aceptado: 22/03/2019

\begin{abstract}
Resumen
Este artículo aborda la problemática de la configuración de las élites hondureñas previo al golpe de Estado del 2009 que derrocó el Gobierno del presidente José Manuel Zelaya Rosales. Ese y otros sucesos posteriores provocaron una de las mayores crisis sociales y políticas en Honduras en los últimos 50 años. Con el golpe de Estado del 2009 se destruyeron casi treinta años de gobernabilidad democrática establecida desde la Asamblea Nacional Constituyente que generó la última Constitución del país, ello después de casi veinte años de gobiernos militares. Dos meses luego del golpe se publicaron las primeras interpretaciones explicando los orígenes, a corto y mediado y hasta largo plazo de los sucesos de 2009. Un foco de atención de esas interpretaciones perfiló como protagonistas a los personajes más conspicuos y miembros de una llamada "oligarquía" capitalista hondureña. Este artículo contextualiza esta interpretación históricamente y ofrece una hipótesis al respecto.
\end{abstract}

Palabras clave:élites, oligarquía, capitalismo, etnoracial, etnohistoria, árabe-palestinos.

\begin{abstract}
This article addresses the problematic formation of Honduran elites prior to the Coup d'etat in Honduras that in 2009 overthrew the government of PresidentManuel Zelaya Rosales. That and subsequent events generated one of the most important political and social crises in Honduras during the last 50 years. The coup of 2009 destroyed almost thirty years of democratic governance established after a National Constituent Assembly in 1982 forced the transition to civilian rule after almost twenty years of military regimes. Two months after the 2009 coup a focus of interpretations of its key events profiled the protagonists who were evident members of a so-called capitalist "oligarchy" composed of 10 to 12 elite families. This article contextualizes this interpretation in historical context, and it offers an argument and hypothesis about said interpretation.
\end{abstract}

Keywords: elites, oligarchy, capitalism, etnoracial, ethnohistory, arab-palestinians. 


\section{Introducción}

El 28 de junio del 2009, el presidente de Honduras, José Manuel Zelaya Rosales, fue derrocado mediante un golpe de Estado que con escasas excepciones fue universalmente condenado. Desde los primeros días del golpe, circularon distintas interpretaciones de los sucesos inmediatos y sus orígenes históricos, ya fueran estos de corto, mediano o largo plazo. Las perspectivas teóricas, ideológicas e insumos documentales para sustentar polémicas y argumentos desplegados en publicaciones de distinta índole han variado mucho durante la última década. Un eje clave en muchos aportes explicativos del golpe de Estado ha sido el accionar de las élites económicas hondureñas en la organización, financiamiento y sostenimiento del golpe de Estado mediante el régimen de facto liderado por Roberto Micheletti Bain, entre junio del 2009 y enero del 2010. Víctor Meza, Ministro de Gobernación del presidente Zelaya y analista de la vida política de Honduras desde fines de la década de 1970, el 10 de octubre del 2009 caracterizó los sucesos del 2009 como un "golpe de las élites" (Meza, 2009). Meza editó un importante libro donde se presentaron muchos datos sobre lo que se llamó "poderes facticos". Este libro se divulgó ampliamente dentro y fuera de Honduras (Meza, 2007).

Para agosto del 2009, segmentos de la emergente Resistencia contra el golpe de Estado hicieron publicar reportajes periodísticos circulados por internet, en los cuales se perfilaban las "10 familias que financiaron el Golpe de Estado", lista derivada de los ensayos publicados en el libro editado por Meza en el 2007. Ya para el 2010 Meza y sus colegas habían elaborado esta perspectiva (Meza, 2010). Por medio de las más polémicas e ideologizadas publicaciones periodísticas y hasta mediante un grafiti popular pintado en las paredes urbanas del país (Frewen), el accionar previo y durante del golpe de Estado de élites hondureñas de ascendencia árabe y judía se denunció con xenofobia y racismo crudo. El Consejo Hondureño de la Empresa Privada denunció ese racismo subalterno (Consejo Hondureño de la Empresa Privada). Publicaciones posteriores en América Latina repitieron esta perspectiva (Velásquez).

Prominentes intelectuales que apoyaron el golpe de Estado también insertaron en sus análisis de las causas y problemáticas del golpe el accionar de los estratos élites de la sociedad y de la economía hondureña (Martínez, 2010; Martínez, 2009; Indiano, 2009. Por su parte, el Informe de la Comisión de Verdad, constituida por la Plataforma de Derechos Humanos, también incluye un análisis de "élites económicas", "grupos económicos" y "poderes fácticos" que accionaron en el golpe de Estado en defensa de un nuevo modelo económico establecido en las décadas de 1980 y 1990 (Comisión de Verdad). Los autores también recurrieron en gran parte a los ensayos de Poderes fácticos, editado por Víctor Meza.

El Informe de la Comisión de Verdad es el único estudio que ofrece una caracterización de las "élites" o "grupos económicos" hondureños; este arroja luz sobre una 
nueva estructura de sectores élites distintos a los que registra la historiografía de las élites hasta la década de 1990 (Euraque, 2009a). Según este informe:

El nuevo modelo económico ha provocado transformaciones en las estructuras de los grupos económicos y en otros aspectos de la vida social. Consistentemente se ha favorecido a los grupos nacionales, regionales y transnacionales vinculados a la economía de servicios y de las exportaciones no tradicionales...

El enriquecimiento de estos grupos y élites empresariales es producto de la devaluación, y de otra serie de medidas estatales como las exoneraciones, leyes de incentivos a la producción, concesiones y liberación de servicios entregados a los negocios privados. En esta lógica, se han aprobado, con mayor énfasis desde los años noventa a la actualidad, un conjunto de leyes para favorecer a las élites empresariales, como la Ley General de Minería, Ley de las Zonas Libres de Procesamiento, Ley de Modernización Agrícola, Ley de Telecomunicaciones y la Ley de Incentivos al Turismo, entre otras. Leyes que se decretan en países con un perfil conservador para una mayor concentración del ingreso (Comisión de Verdad 44-45).

El Informe de la Comisión oficial para esclarecer los antecedentes del golpe del 2009 es muy distinto (Comisión de la Verdad y Reconciliación).

Como casi todos los estudios económicos, sociológicos y políticos a los que recurren los autores del Informe de la Comisión de Verdad para evidenciar sus argumentos históricos, en este informe se menosprecia la dimensión etnoracial de los llamados "grupos económicos" hondureños y su historia en el devenir del sistema político de Honduras previo y durante las décadas de 1980 y 1990. Los análisis de la historia política, y particularmente los análisis realizados por sociólogos y politólogos extranjeros, han marginado sistemáticamente este importante aspecto que desde de la Colonia, hasta el siglo XIX, y bien entrado el siglo XX, distinguió la conformación socioeconómica de las élites de Honduras (Mahoney; Robinson; Jackson; Crosby).

Ni Mahoney ni Robinson, ni Jackson, ni Crosby, a pesar de su vasta lectura de materiales sobre Honduras, consideran la importancia del aspecto etnoracial de los árabe-hondureños en la cúpula de las élites económicas del país. Otra fuente muy citada en el extranjero reconoce "pequeñas comunidades de árabes y libaneses (mal llamados turcos) que desempeñan un importante papel la industria y comercio del país" (Norwsworthy y Barry 127); sin embargo, esta fuente desprecia el tema y sus implicaciones por completo. De hecho, los estudios más actualizados y recientes tampoco consideran la historia etnográfica de las élites hondureñas, aun cuando reconocen el peso cuantitativo de familias o apellidos árabe-palestinos en la cúspide del capital industrial, maquilador y financiero en la transformación capitalista de 1990 en delante (Sosa). 
Estudios recientes de las élites siguen, por lo menos, reconociendo el fuerte peso migratorio desde el Medio Oriente en los grupos económicos de Honduras, desde comienzos del siglo XX (Discua Cruz), tema que abordamos desde comienzos de la década de 1990. Algunos han fundamentado sus argumentos particulares de acuerdo con esas investigaciones, agregando más detalles mediante entrevistas con personajes conspicuos de las generaciones más recientes de los palestino-hondureños (Indiano, 2014).

Siglos antes de la inmigración árabe-palestina a Honduras, ya a fines de la Colonia, las otrora famosas minas producían tan solo un poco de plata. Incluso un resurgimiento a finales del siglo XVIII fracasó. La plata de Honduras solo alcanzó cerca del cinco por ciento de la producción colonial y su renacimiento, a finales del siglo XIX, nunca la ubicó como un recurso importante en el contexto centroamericano (Newson). Un extenso estudio sobre la economía de Honduras decimonónica concluyó que "los hondureños 'súper-ricos"... cuando se comparan con los de las otras naciones centroamericanas, lucen bastante modestos y con poder limitado" (Guevara-Escudero 117).

Las caracterizaciones sobre la pobreza de Honduras y sus alcances se repitieron en el siglo XX (Barahona). La "pobreza de la élite" hondureña asumió una peculiaridad que diferenció al país de sus vecinos centroamericanos, de aquí una broma que circuló en la década de 1980, acerca de que Honduras no pudo ni permitirse "una oligarquía" (Euraque, 1997). En este análisis, la naturaleza de "una oligarquía" tenía alcances mayores a los de la noción aristotélica común de una forma de gobierno en la cual el poder es ejercido por unos pocos. Más bien, en el contexto centroamericano "las oligarquías" han sido asociadas con élites cuyo poder político ha dependido de su monopolio de los recursos económicos: usualmente la tierra y, en el siglo XX, tierra cultivada con productos para la exportación, en un principio café y banano, a partir de 1870. Se remarcó la "oligarquía ausente" de Honduras (Euraque, 1991).

En este escenario, la broma sobre la pobreza y la "ausencia" de una oligarquía -histórica y actual- en Honduras también implica que el cultivo de café y banano nunca sirvió como base extensiva y ni siquiera para un gobierno oligárquico terrateniente; y, peor aún, se conformaron históricamente segmentos de una élite nacional, con nexos regionales, estrechamente dependientes de un sistema concesionario y sus correspondientes mentalidades y mecanismos de clientelismo político partidario articulado al sistema político (Euraque, 1996). Ello devino en la segunda mitad del siglo XX de un Estado concesionario cuyas políticas públicas de desarrollo también se integraron a ese sistema (Seppänen).

Sea como sea, la economía agroexportadora bananero-concesionaria no produjo un capital millonario entre las élites hondureñas. Por ejemplo, en 1947, el embajador estadounidense en Tegucigalpa informó que en Honduras solo vivían seis familias millonarias y que ninguna poseía dos millones de dólares o más (Leonard). En 1949, el Fondo Monetario Internacional (FMI) reconoció que en Honduras "pocos capitales 
excedían más de los 500000 dólares" y que "un hombre considerado rico difícilmente podría ser caracterizado como tal en otro país latinoamericano" y que "ninguna de las fortunas nacionales ha sido amasada por medio de la agricultura" (Márquez et al.) nacional o de exportación, en su mayoría en manos de empresas norteamericanas, la United Fruit Co. y la Standard Fruit Company. A este contexto económico lo acompañó un sistema político particular, en el cual una "oligarquía terrateniente" agroexportadora nunca ejerció el poder político estable.

En este desarrollo histórico, un elemento clave para comprender lo distinta que ha sido Honduras, en la conformación de sus élites en Centroamérica, es el hecho de que en esta mal llamada "república bananera" se generó una élite económica compuesta por actores predominantemente comercial-mercantilistas $\mathrm{y}$, sobre todo, de ascendencia árabe-palestina, cuyos principales capitalistas, aún en la década de 1950, carecían de la ciudadanía hondureña. Por lo tanto, estas élites carecían de presencia o gestión política electoral. Si bien en el resto de Centroamérica la tradicional clase económica dominante, criolla-mestiza, se fundamentó en dos fuentes tradicionales de poder político; en Honduras, el control sobre la tierra en cultivos de exportación -café y banano- dio lugar a otro proceso: un "Liberalismo abortado" (Mahoney). El sistema político hondureño con frecuencia sucumbía ante los caudillos militaristas de los partidos políticos por sí solos, o bien, ante alianzas entre estos últimos y la política interventora de las empresas bananeras extranjeras y la política exterior de los diferentes gobiernos de EE. UU., con escasa incidencia cohesiva y coherente de una "oligarquía terrateniente".

Dejar por fuera la dimensión etnoracial de la conformación generacional de las altas esferas de las élites económicas en Honduras, como en general se ha hecho, es un error historiográfico grave si se quiere conocer a fondo los antecedentes del golpe de Estado del 2009. Además de las publicaciones ya referenciadas, las más recientes tampoco abordan este tema (Villacorta y De Gori). Cuando sí se registra algo sobre los árabe-palestinos en Honduras, se mal interpreta, o su significado no es perfilado como se le amerita. Ejemplo de lo primero es un trabajo publicado en el 2005, en el cual se afirmaba que los "árabes hoy están completamente integrados en la sociedad hondureña en todos los nivele" (Bull 136-137). En tanto que, un ejemplo de la caracterización superficial del tema es la simple afirmación de que Honduras en el 2009 era gobernada por "una docena de familias prominentes casadas entre si conocidas como 'oligarcas', muchas descendientes de origen palestino-cristiano" (Frank 2).

Lo anterior es llamativo dado que en este trabajo se aborda el surgimiento de nuevas inversiones privadas, más allá de la tradicional economía agroexportadora, incluso, en la generación de electricidad en Honduras en la década de 1990, cuya etnogenealogía eran los empresarios árabe-hondureños, Chucry Kafie y Fredy Nasser (Romero 122). Nasser está casado con una hija de Miguel Facusse, a quien muchos denuncian como principal organizador del golpe de Estado. Por último, el hecho de que la historiografía contemporánea también ha menospreciado el contexto de la transformación 
agraria, en la cual se destacó Miguel Facusse en la década de 1990, antes de su muerte en el 2015, ello con inversiones en Palma Africana en el Valle del Aguán, generó un polo agrícola de acumulación capitalista árabe-hondureño distinto a los textileros o comestibles (León y Edelman; León).

Menospreciar la dimensión etnohistórica de las élites hondureñas durante el siglo XX menoscaba la comprensión profunda de la relación entre el pasado hondureño, la antesala inmediata del golpe de Estado, el accionar político de los personajes más representativos de los grupos económicos de poder en la organización, financiamiento y defensa del golpe de Estado del 28 de junio del 2009. Por lo tanto, el grado de ruptura que representaron los sucesos posteriores al golpe del 2009, incluida la masiva Resistencia popular y su representación actual en el Partido Libertad y Refundación. En esa interpretación es superficial el racismo y la xenofobia subalterna en contra de "los árabes" y "los turcos" luego del golpe de Estado del 2009 se originaron en aspectos de la configuración etnohistórica de las élites hondureñas.

El objetivo aquí es historiar, a grandes rasgos, la conformación etnoracial de las élites de Honduras como insumo fundamental a la reflexión actual sobre las "transformaciones en las estructuras de los grupos económicos y en otros aspectos de la vida social" de Honduras. Partimos sosteniendo que no fueron "10 familias" las que dieron el golpe de Estado del 2009. En cuanto al segmento de élites económicas que participaron en la coordinación del golpe de Estado del 2009 y su sostenimiento, argumentamos que por lo menos las caras públicas fueron personajes asociados con una fracción transnacional del capital hondureño que consolidó su poder económico en la transición entre la década 1990 y la primera década del siglo actual. En su seno social y cultural predominan familias árabe-hondureñas que carecen del capital político-cultural para legitimar su hegemonía en el contexto particular del sistema político hondureño regido por el bipartidismo caudillista del Partido Nacional y Liberal (Euraque, 2006). Si las élites árabe-hondureñas participaron en el golpe de Estado fue más por su carencia de hegemonía sobre el poder político y el Estado, y el hecho que carecen del capital político-cultural para imponer dicha hegemonía aun cuando sustentan amplio poder económico en el capitalismo transnacional que se consolidó durante las últimas dos décadas.

\section{Los árabe-hondureños en la economía de Honduras, 1950-1980}

La cumbre de la economía nacional durante la década de 1980 se encontraba en manos de familias árabe-hondureñas de segunda y tercera generación, las cuales apenas comenzaban a participar públicamente en el poder ejecutivo del Estado. Nuestra hipótesis es que estos eran hijos e hijas de una importante coyuntura económica y política en la historia de Honduras: la transición a la democracia luego de la dictadura del General Tiburcio Carias Andino a fines de la década de 1940 y la presidencia de 
Juan Manuel Gálvez, entre 1949 y 1954. En Honduras, a partir de la Segunda Guerra Mundial, los mal llamados "turcos", ya en segundas generaciones, comenzaron un proceso de naturalizaciones que los convirtió en ciudadanos hondureños, por lo menos en su sentido legal, sino quizás en el sentido identitario como hondureños con arraigo cultural reconocido por los subalternos hondureños y hondureñas (Euraque, 2006).

En esta época

los árabe-palestinos registraron el mayor número de naturalizaciones ante el Estado de Honduras. Entre julio de 1946 y junio de 1956 se naturalizaron 825 inmigrantes ante la Secretaria de Relaciones Exteriores. De estos, 294 se registraron como palestinos, o el 36 por ciento; en segundo lugar, se registraron Salvadoreños, con 117 naturalizaciones y nicaragüenses con 66 naturalizaciones, seguidas por los españoles, con cincuenta y dos (Euraque, 2006, 281).

En fin, parecen ser los nietos y nietas de aquellas generaciones de árabe-palestinos naturalizados en las décadas de 1940 y 1950, quienes hoy forman parte de la cúpula de la burguesía hondureña. A diez años de la ruptura provocada por el golpe de Estado, merece escudriñarse más que nunca, siempre en su contexto histórico, en particular porque un hondureño de extracción árabe-libanes, Salvador Nasralla Salum, nacido en Tegucigalpa en 1953, de madre chilena-palestina, fue el candidato presidencial en las elecciones de noviembre del 2017. Representaba una alianza de partidos de oposición, encabezada por el expresidente Zelaya Rosales y su partido Libertad y Refundación (El Heraldo). No solo fue totalmente innovadora la alianza política como mecanismo electoral en Honduras, única en su historia, sino el hecho de que un personaje como Nasralla Salum fue ampliamente respaldado por casi medio millón de votantes y aliado con un descendiente de hondureños criollos con ascendencia colonial.

En seguida, se perfila la estructura de las élites económicas de Honduras y su distribución sectorial, hasta la transición a la década de 1980. Además, se caracteriza su composición social y distribución territorial hasta fines de la década de 1970. En su conjunto, estas problemáticas se abordan en varias siguientes secciones. Estas son resúmenes de investigaciones históricas realizadas durante los últimos 30 años. De esta manera, el accionar y la motivación de personajes de los "grupos económicos", "élites económicas" y las supuestas "10 familias" en el golpe de Estado del 28 de junio del 2009 y su defensa se podrán abordar con mayor detalle, sobre todo al intentar vincular acciones y motivaciones con las transformaciones en las estructuras de los grupos económicos y en otros aspectos de la vida social en las últimas dos décadas.

Después de 1945, el producto interno bruto de Honduras (PIB) aumentó de 264 millones de dólares a 370 millones de dólares en 1955 y a 602 millones de dólares en 1965. En 1970, la cifra se mantuvo en 73.8 millones de dólares. El sector manufacturero del PIB en Honduras aumentó continuamente después de la Segunda Guerra Mundial, alcanzando cerca del $4.5 \%$ del PIB en 1949, $7.5 \%$, en 1959, y $10.0 \%$ en 1969. Cambios 
significativos con respecto a las décadas del veinte y del treinta, cuando la manufacturación sumaba poco más del $3 \%$ del PIB. Después de la Segunda Guerra Mundial, el sector agrícola del PIB continuó como el principal componente de la economía, pero la contribución del sector exportador siguió en declive, con la agricultura para uso doméstico asumiendo un rol cada vez más importante. En 1939, el porcentaje de la contribución de la agricultura de exportación al PIB permaneció en un $22.9 \%$; mientras que, en 1949, la cifra cayó al 19.6 \% y se estabilizó en $12.7 \%$ en 1959.

La incorporación de Honduras en el Mercado Común Centroamericano (MCCA) sumó elementos nuevos y dinámicos a estas medidas macroeconómicas de conjunto. Uno de los elementos más cruciales discutido en la literatura del MCCA se relaciona con el capital de inversión empleado en la intensificación de la industrialización manufacturera en América Central durante la década de 1960. Toda Centroamérica descubriría claramente que la Inversión Directa Extranjera (IDE) en manufacturación en la década del sesenta vino a darle el control general de ese sector económico primariamente al capital estadounidense. En Honduras los números fueron perfectamente claros ya a finales de la década de 1960, con varios estudios que especificaron el grado de control extranjero sobre las mayores empresas manufactureras, medido, por lo general, según el valor del rendimiento productivo, la mano de obra empleada y los márgenes de beneficio.

Por su parte, las estadísticas macroeconómicas nacionales enmascararon el poder económico regional de la Costa Norte y de San Pedro Sula, en particular, en ese marco el poder económico de los árabe-palestinos. En 1970, el departamento de Cortés representó cerca del 55 por ciento de la producción manufacturera con base fabril del país, mientras que Francisco Morazán -el departamento donde se encuentra Tegucigalpa- registró una medida paralela de solo el 25 por ciento, aproximadamente. Asimismo, los establecimientos manufactureros de San Pedro Sula representaron un mayor valor en cuanto al capital invertido en bienes fijos, si se compara con medidas similares para Tegucigalpa.

Ahora bien, los datos de 1969 muestran que las fábricas de San Pedro Sula, en el Valle de Sula y la costa caribeña de Honduras, empleaban a cerca de 8050 trabajadores; mientras que las de Tegucigalpa a 6800, aproximadamente. Finalmente, las fábricas de San Pedro Sula empleaban como promedio a más trabajadores por fábrica que las de Tegucigalpa y pagaban como promedio salarios más altos que en cualquier otro lugar del país. En resumen, durante la década de 1960 San Pedro Sula se convirtió en la "capital industrial" del país. Así, los árabe-palestinos de primera generación se convertían en poderes económicos fundamentales en el país. Estas experiencias históricas fueron la base del impulso de la industria maquiladora en la transición entre las décadas de 1980 y 1990, ya con árabe-hondureños de segunda y tercera generación.

Muchos factores contribuyeron con este proceso, incluido el acceso fácil y rápido de San Pedro Sula a Puerto Cortés, el puerto más importante del país, especialmente después de haber recibido una costosa reparación en 1966. El acceso directo a 
los mercados de las plantaciones bananeras contribuyó ciertamente al aumento de la capacidad productiva, especialmente en el sector de bienes de consumo. La población en rápido crecimiento en y cerca de San Pedro Sula también se sumó a las nuevas posibilidades de mercado para el desarrollo del proceso manufacturero. No obstante, el factor más crucial para establecer de hecho nuevas fábricas y rehabilitar otras tuvo que ver con una movilización de capital para la producción manufacturera a una escala nunca vista antes de la década de 1960. Como ha quedado demostrado en este estudio, la riqueza doméstica en Honduras raramente había estado desplegada sistemáticamente en la producción manufacturera. La Ley de Desarrollo Industrial de 1958 cambió las condiciones en lo concerniente a arriesgar capital acumulado en manufacturación y, en San Pedro Sula, un círculo de comerciantes e industriales -particularmente familias árabes- tomó ventaja de este nuevo incentivo y también adoptó modelos de inversión históricos antes de 1960.

Después de la Segunda Guerra Mundial, la Standard Fruit Company de la Ceiba continuó un proceso de diversificación que databa de las primeras décadas del siglo XX en aquella región, pero cuyos comienzos en San Pedro Sula habían ocurrido en la década de 1930. Por la época del MCCA, las empresas de la Standard Fruit Company, apoyadas por recursos del Banco Atlántida, se consolidaron en una estructura financiera crucial alrededor de la cual se organizó localmente la burguesía sampedrana. Este modelo histórico de industrialización periférica en San Pedro Sula permitió nuevas y más dinámicas formas de acumulación manufacturera en las décadas de 1950 y 1960. No obstante, el proceso también significó el surgimiento de un nuevo tipo de Comercio Faustiano, un comercio que, en última instancia, fijó nuevos límites para el potencial social y político, y para las expectativas de la burguesía, a pesar del hecho de que algunos individuos pensaran alguna vez lo contrario.

El complejo cervecero, organizado por la Standard Fruit Company desde finales de la década de 1930, era la industria manufacturera que empleaba a más trabajadores durante las décadas de 1940 y 1950, fuera de las industrias azucareras y de indumentaria. Este conjunto de empresas empleaba entre 270 y 380 o más trabajadores hacia principios de la década del cincuenta. La trayectoria de las inversiones de la Standard Fruit Company en la Cervecería Hondureña, S. A. (CEHSA), desde la década de 1930 hasta principios de la del sesenta, muestra la complejidad y los detalles íntimos de un grupo de inversión que controlaba directamente casi todos los principales asuntos manufactureros antes del MCCA, incluyendo las plantaciones de caña y refinerías azucareras, los molinos harineros y la fábrica de cemento; esto es, la mayoría de los empleadores fabriles de la ciudad aparte de la industria de indumentaria.

Como se anotó antes, el establecimiento de este complejo cervecero en San Pedro Sula databa de la década de 1930, mucho después de que la Standard Fruit Company hubiera establecido una cervecería en la Ceiba conocida como Compañía Industrial Ceibeña (CIC). En 1935, Antonio Mata y Reginald Hammer, representantes de la 
Standard Fruit Company, organizaron la CEHSA, probablemente como un holding que más adelante absorbió a la Cervecería Unión, S. A. (CEUSA) de San Pedro Sula, una pequeña cervecería establecida por socios de Samuel Zemurray (Cohen) a finales de la década de 1920. ${ }^{1}$ En febrero de 1939, los socios de la Standard Fruit Company establecieron la Compañía Embotelladora Hondureña, S. A. (COEHMSA), la cual unos pocos meses después absorbió a la CEUSA. Los inversionistas de la COEHMSA incluían a la mayor parte de los de la CEUSA.

En 1944, CEHSA, firma establecida en 1935, se convirtió en el holding que comprendía a la CIC y a la COEHMSA, probablemente en un esfuerzo por competir con una cervecería propiedad de alemanes en Tegucigalpa. En 1949, CEHSA obtuvo otra concesión importante a través del presidente Juan Manuel Gálvez, quien poseía algunas acciones en el complejo cervecero desde finales de 1930. A finales de 1951, la CEHSA absorbió finalmente a la COEHMSA y a la CIC. En 1952, CEHSA controlaba las industrias cerveceras y embotelladoras de San Pedro Sula, Puerto Cortés y La Ceiba.

Después de 1951, la principal accionista de la CEHSA seguía siendo la Standard Fruit Company. Sin embargo, la CEHSA también incorporó en su estructura de capital a la mayor parte de los más importantes comerciantes y manufactureros inmigrantes de San Pedro Sula, incluyendo a José Brandel, Antonio Mata, Boris Goldstein, Elías J. Kattan, Yankel Rosenthal, Jacobo Weizenblut y socios de los Canahuati, Siwady y Yuja. No obstante, la conexión entre estos inversionistas y la CEHSA no se originaba únicamente a través de este canal. Las relaciones en expansión pueden ser vistas también a través de otros procesos, especialmente el de la organización de las plantaciones de caña y de las refinerías azucareras en la región en esa época. Estas surgieron como el primer gran complejo de compañías hecho público en el período, todas íntimamente relacionadas con las familias árabes más importantes de San Pedro Sula.

En 1931, Samuel Zemurray, muy próximo entonces para convertirse en el presidente de la United Fruit Company, animó a su viejo amigo Roberto Fasquelle a sembrar caña de azúcar (Pastor Fasquelle, 2019). Ayudado por una importante concesión, Fasquelle reorganizó su empresa familiar en 1938 con accionistas que la élite comercial árabe sampedrana, incluyendo a los Larach y a los Siwady, pero también árabes de Tegucigalpa, los Facussé y Barjum. Fasquelle también incluyó a líderes políticos nacionales y locales, desde el General Abelardo Bobadilla y el Coronel Eduardo Galeano del Departamento de Cortés, hasta el entonces Ministro de Gobernación, Juan Manuel Gálvez. En las décadas de 1940 y 1950, la Compañía Azucarera Hondureña, S. A. (CAHSA), de Roberto Fasquelle Orellana, surgió como una de las pocas empresas que recibían préstamos importantes del Banco Atlántida.

La única industria importante que la Standard Fruit Company llegó a controlar durante la década de 1950 fue la industria cementera hondureña, organizada también por importantes comerciantes y manufactureros sampedranos. Los esfuerzos para establecer Cementos de Honduras, S. A. (CEMSA) nacieron en 1948 con Antonio Mata, 
un rotario sampedrano y ejecutivo de la compañía bananera. El proyecto de Mata no llegó a materializarse, pero, en 1952, el BNF empleó a un experto de las Naciones Unidas para estudiar nuevamente la posibilidad. El experto escogió a San Pedro Sula como centro de operaciones para una fábrica que iba a ubicarse a unos pocos kilómetros del lugar donde la materia prima estaba fácilmente disponible. Los comerciantes y manufactureros sampedranos compraron la mayor parte de las acciones iniciales en 1956, con el vicepresidente de la CCIC Jude Canahuati como el mayor accionista individual, seguido por inversionistas como Yankel Rosenthal, el antiguo funcionario del FMI Paul Vinelli, el director del CNE, Jorge Bueso Arias, José Brandel y muchos de los comerciantes y manufactureros inmigrantes de San Pedro Sula y La Ceiba.

La gama de inversionistas regionales de la CEMSA representaba una innovación relacionada con los niveles acentuados de acumulación comercial registrados en la Costa Norte durante el período de reactivación económica posterior a la Segunda Guerra Mundial. No obstante, otros elementos de la estructura de la CEMSA también evidenciaban la creciente complejidad de los modelos de inversión. La estructura de inversión de la CEMSA incluía no solo a una amplia gama de inversionistas individuales que compraban una "compañía públicamente constituida", sino que también representaba una concentración de "inversiones institucionales" por parte de importantes empresas locales, un proceso de movilización de capital específico de este período e innovador en San Pedro Sula. Los inversionistas corporativos de la CEMSA incluían a Luis Kafie y Cía., Jorge J. Larach y Cía., Jacobo D. Kattan Industrial, S. A., Elías J. Kattan y Cía., Antonio D. Kattan y Cía., incluso al BNF. En 1959, la CEMSA aumentó su capital activo al aceptar mayores inversiones de la Cervecería Tegucigalpa, S. A. y Cervecería Hondureña S. A., ambas bajo el control de la Standard Fruit Company.

La industrialización capitalista de San Pedro Sula también se benefició de préstamos importantes por parte de instituciones inspiradas por el MCCA, como el Banco Centroamericano de Integración Económica (BCIE), incluso de la Agencia Internacional para el Desarrollo de los Estados Unidos (USAID, por sus siglas en inglés). En Honduras estas fuentes externas de capital eran mejor utilizadas por la burguesía sampedrana. El BCIE se convirtió inmediatamente en el principal acreedor de las inversiones en manufacturación con base fabril en Honduras. En el proceso, el BCIE apoyó ampliamente a empresas grandes controladas por el grupo inversor de la Standard Fruit Company de San Pedro Sula, surgido en la década de 1950.

Asimismo, entre 1961 y 1962, el recién establecido Centro para la Cooperación Tecnológica e Industrial, supervisado por asesores de la USAID, contactó a los manufactureros más importantes del país y les alentó a establecer un banco de inversión industrial capaz de movilizar capital local para empresas manufactureras. Este esfuerzo se consolidó en el establecimiento en enero de 1964 de la Financiera Hondureña, S. A. (FICENSA) en San Pedro Sula. Unos pocos meses después, FICENSA recibió un préstamo de cinco millones de dólares de la USAID. En 1966, la USAID otorgó otros 
tres millones de dólares y el BCIE concedió a FICENSA importantes préstamos en 1971. En cualquier caso, hacia finales de 1965, FICENSA se convirtió en la principal fuente de crédito para la manufactura a largo plazo en Honduras y en el canal institucional para las inversiones de capital extranjero destinadas, la mayoría de ellas, a firmas calificadas bajo la Ley de Desarrollo Industrial de 1958.

Mientras los préstamos de los Estados Unidos se constituyeron en la principal fuente de capital de FICENSA en 1964, los importantes comerciantes y manufactureros sampedranos eran sus mayores inversionistas individuales incluyendo nombres familiares en aquella época: Gabriel A. Mejía, Jude Canahuati, José Brandel, Yankel Rosenthal, Antonio Mata, Berti R. Hogge, Boris Goldstein, Nicolás J. Larach, Jorge J. Larach, Jaime Rosenthal, Jacobo D. Kattan y otros. Estos inversionistas individuales estaban a su vez íntimamente ligados a los "inversores corporativos" que compraron acciones de FICENSA en 1964. De esta manera, la industrialización de la posguerra sirvió como marco para un nuevo papel de los árabe-hondureños en la economía de Honduras, consolidado en la transición entre las décadas de 1960 y 1980. Para esta época surgió también la encrucijada del papel social y político de las nuevas generaciones de árabe-hondureños, ello como antesala al golpe de Estado del 2009.

\section{Los árabe-hondureños y el sistema político de Honduras, 1960-2000}

El etnoracismo que desató el golpe de Estado del 2009 en contra de los personajes "turcos" y árabe-hondureños que formaban parte de las llamadas "10 familias" que supuestamente "financiaron" el derrocamiento del Presidente Zelaya -los Nasser, Facusse, Kafie, Atala- goza de otros precedentes históricos profundos en el pasado hondureño que son prácticamente desconocidos. Fue casi inevitable que la dimensión etnoracial de segmentos claves de la burguesía comercial e industrial hondureña saliera a relucir con la ruptura política del 2009. Sin embargo, no fue la primera vez. Una de las primeras y más recientes veces fueron los militares mismos que apelaron al etnoracismo en contra de los árabe-hondureños (Euraque, 2006; Euraque, 1996a; Euraque, 1996b).

El 19 de septiembre de 1968, El Día, diario conservador de Tegucigalpa de esa época, publicó titulares dramáticos: "La Prensa suspendida anoche"; "Estado de Sitio declarado en todo el territorio nacional"; y "Noticias de última hora: el Gobierno envía tropas a San Pedro Sula". Dos días más tarde, El Día informaba que "Edmond L. Bográn de la Financiera Hondureña S. A., (había sido) obligado a salir hacia Nicaragua". Esa misma fecha El Día publicó información oficial comunicada por el General Oswaldo López Arellano, quien había asumido el poder después de un cruento golpe de Estado en octubre de 1963. En esa comunicación oficial se condenaba una huelga de capital promovida por comerciantes y fabricantes sampedranos, y decretaba que las actividades comerciales se reasumieran dentro del plazo de 24 horas. Los comerciantes y fabricantes serían condenados a multas desde 25 hasta USD 1000, “dependiendo 
de la gravedad de la infracción y del número de trabajadores afectados". Estas penas podrían verse complementadas con otras responsabilidades que las autoridades competentes declarasen.

Finalmente, el comunicado emitido por el General López Arellano reprendía a los elementos foráneos de la burguesía sampedrana por "haber hecho su vida en este país e incluso acumulado riquezas bajo los auspicios de un ambiente protector y fraternal que el noble pueblo hondureño les había proporcionado sin esperar recompensa material" (Euraque, 1996b). Más amenazadoramente, el General López Arellano les advertía a los comerciantes y fabricantes extranjeros participantes en la huelga de capital que serían presentados ante "las autoridades competentes, de manera que según los procedimientos establecidos, sus permisos de residencia podrían ser cancelados e invitados a dejar el país en el lapso de tiempo prescrito por la Ley" (Euraque, 1996b). De acuerdo con El Día, estas amenazas estaban "dirigidas especialmente a los comerciantes árabes de San Pedro Sula". En la antesala del golpe de Estado, el propietario actual de La Prensa, Jorge Canahuati Larach, era nieto del principal accionista de La Prensa (Euraque, 1986), Jorge J. Larach, fundado en 1964.

Para las élites sampedranas, el repertorio informativo de El Día, especialmente la "poca importancia" que se le atribuyó a la destrucción por parte de la policía de las oficinas de La Prensa, confirmó la defensa que hacía aquel periódico del régimen que López Arellano estableció a partir del golpe de 1963. Igualmente importante había sido el Editorial de El Día del 24 de enero de 1967, en el cual se había caracterizado a La Prensa "como propiedad de un consorcio económico de mucho peso en las actividades nacionales", ligando de esta manera sus políticas a los intereses del capitalismo sampedrano. La hostilidad de El Día contra La Prensa era compartida por El Nacional, también publicado en Tegucigalpa. Desde su fundación La Prensa fue blanco de los ataques de El Nacional.

Más revelador fue el hecho de que en julio de 1967, El Pueblo (periódico del Partido Liberal), entonces bajo la dirección de Carlos Roberto Reina, futuro presidente de Honduras (1994-1998) y perteneciente a la Izquierda Democrática de entonces, argumentara: "La Prensa de San Pedro Sula es considerada en todo Honduras como la voz autorizada del sector comercial más poderoso del país". Sin duda los observadores vinculados con El Día y El Nacional compartían esa perspectiva; ello era importante porque ambos periódicos estaban en manos de allegados al Partido Nacional quienes, a partir de 1965, sirvieron como eje partidario del gobierno militar instalado en primera instancia a fines de 1963. El ataque etnoracial de parte del General López Arellano, relacionado con una famosa huelga de capitales de 1968, es prácticamente desconocido en la historia política de Honduras. Cuando se aborda la huelga, desaparece por completo el tema etnoracial, aun por parte de los más destacados observadores.

A partir de 1972 (especialmente entre 1972 y 1975), el General López Arellano estableció alianzas muy diferentes con sectores de la oposición en la huelga de 1968, incluyendo sectores de la burguesía de San Pedro Sula. De esta manera, se impulsó un 
reformismo militar muy semejante al encabezado por el General Omar Torrijos en Panamá y al del General Juan Velasco en el Perú en aquella época. Muchos militares hondureños entregados al reformismo militar habían estudiado en Panamá o en Perú a fines de la década de 1960. El Estado desarrollista hondureño de aquellos años, con la formación en 1974 de la Corporación Nacional de Inversiones (CONADI), se comprometió a fomentar el sector industrial nacional. Los hondureños de ascendencia árabe-palestina fueron los mayormente beneficiados, igual que algunas familias de ascendencia judía con intereses comerciales e industriales en San Pedro y Tegucigalpa.

Existe una importante relación entre el desarrollismo industrial de la década de 1970 y la vida política de las décadas posteriores, la cual se ha menospreciado y carece de investigación histórica. Evidenciar y rescatar la relación histórica entre el desarrollismo industrial, su vínculo con la estructura socioeconómica, y ciertas implicaciones para la transición a la democracia en Honduras en las décadas de 1980 y 1990 es el objetivo principal de este trabajo. Las investigaciones existentes sobre la transición a la democracia se refieren (solo efímeramente) a la historia socioeconómica hondureña previo a la década de 1980; ello a pesar de los avances que la historiografía sobre estos temas registró durante las últimas dos décadas.

Ese contexto histórico y socioeconómico es sumamente importante para comprender mejor el ascenso al poder de los presidentes Rafael Leonardo Callejas Romero (1990-1994), Carlos Flores Facussé (1998-2002) y Ricardo Maduro Joest (2002-2006). Desde las Ciencias Sociales, a partir de fines de la década de 1970, el sociólogo Mario Posas fue pionero en comentar aspectos raciales en la historia de Honduras, especialmente la dinámica de los movimientos obreros en la Costa Norte del país. No obstante, es desde hace poco tiempo que la situación de los árabe-palestinos en el contexto del análisis histórico de la identidad nacional y la estructura social comenzó a recibir alguna atención seria. ¿Por qué?, ¿con qué implicaciones para la transición a la democracia en Honduras en la década de 1980?

En primer lugar, pesaba sobre el asunto el mito oficial, solamente cuestionado hasta la década de 1990, acerca de que el origen racial de todos (o la mayoría) de los hondureños era "el mestizaje" en el sentido reducido del término, "hijos de españoles e indios", con quizás un "poquito" de negro (Euraque, 2004). Por lo tanto, el análisis de la identidad nacional, en su aspecto etnoracial, debía comentarse en torno a las dos, a veces tres, razas de la nacionalidad, en particular en su origen colonial. Al ser ese el paradigma étnico-racial hasta la década de 1990, el análisis de la presencia árabepalestina dentro de la nacionalidad hondureña se marginó casi por completo. Es más, existen indicios para suponer que los defensores de los árabe-palestinos, ante el ataque étnico-racial, asumen los propios mitos del mestizaje oficial; es decir, que la nacionalidad debe definirse reducidamente en relación con una ascendencia hispano-indígena, excluyendo la negritud. 
Al respecto, como se anticipó, se cita un editorial del diario La Tribuna publicado el 9 de febrero de 1983, en los albores de la transición a la democracia bajo el gobierno de Roberto Suazo Córdova (1982-1986), viejo caudillo del Partido Liberal. En aquella ocasión, los editorialistas de La Tribuna, cuyos propietarios principales eran árabehondureños, los Facussé, comentaban el hecho que un diputado del Partido Nacional condenara al gobierno de Suazo Córdova diciendo que "en este gobierno las cosas no se hacían en misas negras sino en misas turcas". Los editorialistas de La Tribuna, sostenían que "esta expresión deja entrever claramente un profundo sentimiento racista, un ferviente deseo de inducir en la conciencia social el elemento disociador del racismo".

Más aún, los editorialistas decidieron ahondar sobre el tema mediante observaciones de suma importancia en este contexto. Por ejemplo, señalaban:

Los turcos... no vinieron a Honduras como trashumantes, como gitanos... Muestra de ello es que se han nacionalizado e incluso algunos han olvidado el lenguaje y las costumbres maternas para fusionarse con los hondureños autóctonos en una sola e indivisible estirpe mestiza (Euraque, 2009, 257).

Además, señalaba el mismo editorial: "las nuevas generaciones de padre o madre de origen árabe nacieron aquí y son tan indios como cualquier hijo de vecino" (Euraque, 2009, 257). Argumentaban los editorialistas que "hondureños de la pura sangre de Lempira se han caso con 'turcas' o 'turcos', según el caso' (Euraque, 2009, 257). Así, se apelaba a construcciones étnico-raciales y profundamente arraigadas tanto en el ámbito popular como oficial, para luchar contra el racismo entre las élites hondureñas. Desafortunadamente la historiografía de la segunda mitad del siglo XX descuidó casi por completo esta dimensión de la cultura política del país, la cual merece rescatarse, especialmente en el contexto de la transición a la democracia durante la década de 1980.

Las relaciones entre estructuras sociales y sistemas y culturas políticas han sido objeto de estudios en Ciencias Sociales desde el surgimiento en Europa de la sociología moderna en el siglo XIX. En Centroamérica, el aporte de las ciencias sociales para explicar la problemática de la ausencia de sistemas políticos democráticos y la persistencia de culturas caudillistas y autoritarias surgió como importante a partir de la segunda mitad del siglo XX. Desde ese entonces, fue la sociología histórica, y especialmente aquella influenciada por la teoría de la dependencia, la que más sistemáticamente investigó y analizó las relaciones entre estructuras sociales y sistemas políticos en la región.

En Honduras, la historia como disciplina en sí también cayó bajo la influencia de la sociología histórica dependentista en la segunda mitad del siglo XX. Lo mismo sucedió con la subsiguiente historiografía sobre la problemática de estructuras sociales, sistemas políticos y la democracia. Se dieron importantes excepciones, especialmente el peruano Antonio Murga Frassinetti (Euraque, 2012). 
Nuestras investigaciones sobre la historia económica de Honduras y sus implicaciones para para la historia política del país se estimularon de la lectura de los estudios publicados en la década de 1970. Nosotros en nuestra historia económica y social de Honduras cuestionamos esta versión de la relación entre el enclave bananero como estructura social primaria y la sociedad hondureña. Creemos que tanto la nuestra como otras contribuciones más recientes a la historiografía hondureña ofrecen una reinterpretación del llamado enclave bananero y la industrialización posterior, vista desde el contexto latinoamericano, especialmente comparado al nivel de industrialización en México, Chile, Argentina y Brasil.

En este contexto, ¿hasta qué punto los orígenes del eje López Arellano Costa Norte de 1972 pueden ser explicados por la historia específica de la formación de una clase regional en San Pedro Sula y la Costa Norte en general? En mayo de 1973, unos seis meses después de que el General López Arellano retornara al poder, y bastante después de que el nuevo régimen comprometiera al Estado en un proyecto reformista (que en muchas formas parangonaba las experiencias panameñas y peruanas), el Secretario General del Partido Comunista Hondureño aseveró que la burguesía industrial de San Pedro Sula estaba activamente involucrada en los preparativos para derrocar al gobierno de Cruz (en 1972).

¿Había estado la burguesía industrial sampedrana "activamente involucrada" en los preparativos del golpe de 1972? Si así fue, ¿implicó el reformismo posterior a diciembre de 1972 (que el capitalismo hondureño había finalmente producido) una burguesía nacional al estilo de las viejas proyecciones del KOMINTERN?, ¿había sido transformado el reformismo de 1967 y 1968 en una agenda revolucionaria y antiimperialista con base en la clase comercial?, ¿cómo reconciliar este panorama con la presencia de vanguardia de los trabajadores norcosteños y el campesinado en aquella época?

El golpe de 1972 no llevó al poder a una "burguesía industrial nacional" con base en San Pedro Sula. En su lugar, el golpe de López Arellano posibilitó la agenda, el proyecto, de lo que podría ser llamado la visión adoptada por una "burguesía industrial nacional" y por los trabajadores, tal como ambos habían evolucionado en la Costa Norte. Mientras el reformismo de 1972-1975 es central para comprender la estabilidad política del país en la década de 1980, el propio reformismo debe explicarse a la luz de la historia de la Costa Norte hondureña durante la primera mitad del siglo XX. La historiografía y los comentarios generales descartan con frecuencia a la región tras considerarla solo como una gran plantación de las compañías bananeras imperialistas. Esta perspectiva no hace un escrutinio serio de la historia económica, social, cultural y política de la región. En fin, a inicios de la década de 1980, al comienzo de la transición a la democracia, casi nadie en Honduras, o fuera, hubiera cuestionado la aseveración de un eminente intelectual de la época, que a la vez desempeñó cargos importantes en los gobiernos militares reformistas de la década de 1970: “Por desgracia, la historia 
de Honduras es la historia de la explotación bananera por los monopolios extranjeros enclavados en la Costa Norte" (Flores Valeriano).

El renombrado y recientemente fallecido sociólogo centroamericano Edelberto Torres-Rivas argumentó hace mucho que, después de la década de 1950, en la región, la "vieja oligarquía dio paso a una burguesía moderna agroexportadora" (Torres-Rivas). No obstante, Torres-Rivas también puntualizó que las viejas oligarquías, en particular las clases gobernantes cafetaleras de El Salvador y Guatemala, no "desaparecieron" (Torres-Rivas 50). En su lugar, "la clase dominante se modificó levemente. Lo que ocurrió fue una reestructuración interna a la vez lenta y dolorosa que transformó al viejo terrateniente-capitalista en un capitalista-terrateniente" (Torres-Rivas 34). Este análisis es correcto en general para Guatemala, El Salvador y Costa Rica, aunque en el último país con diferentes implicaciones políticas. Sin embargo, el caso hondureño no "calza" en la visión de Torres-Rivas. La burguesía hondureña de finales de la década de 1950 y de la de 1960 no resultó de "una re-estructuración interna" de una vieja "oligarquía".

De hecho, la hostilidad de la mayoría de los hacendados hacia la reforma agraria en la década de 1970 mostró las preocupaciones, no de una vieja y reconstituida oligarquía "clásica" centroamericana, sino de una nueva burguesía rural con lazos íntimos con el capital extranjero. Es más, esta relación, principalmente en los casos del algodón, el azúcar y especialmente la carne, permaneció entrelazada con un grupo comercial industrial relacionado con la Standard Fruit Company desde la década de 1950. No obstante, cualquier tolerancia que el capital imperial, así como la Embajada de los Estados Unidos, hayan mostrado ante visionarios como Rodolfo Pastor Zelaya, Edmond L. Bográn (1930-1989), Jaime Rosenthal Oliva (1936-2019) y otros durante la década de 1960, evidentemente cesó después de 1972.

La ola de industrialización promovida por el Mercado Común Centroamericano animó a una burguesía comercial e industrial y a la militancia trabajadora en San Pedro Sula durante la década de 1960, en cierta forma culminando en los sucesos de 1968. Sin embargo, la simultánea reestructuración de esta burguesía comercial-industrial en una burguesía agraria, también con el capital extranjero, dejó a los visionarios de los sectores manufactureros de la clase-hombres como Edmond L. Bográn y otrosaislados y susceptibles de ser atacados (Euraque, 2013).

Así pues, el golpe de 1972 habilitó aspectos de la visión y el proyecto de Bográn, pero no a sus actores históricos como "una clase", porque esta murió potencialmente en septiembre de 1968, en el fracaso de la huelga de capitales. Es más, esa visión menospreció la historia étnico-racial de la élite comercial e industrial de Honduras. Esa potencialidad murió en 1968 a causa de las particularidades de la historia hondureña del siglo XX en el contexto del capitalismo periférico: desde la integración de Honduras con la economía mundial mediante las exportaciones bananeras al consecuente carácter de la formación de clases en la Costa Norte en general y de San Pedro Sula en particular. Por su parte, las victorias del reformismo de la Costa Norte, que en muchas 
formas constituyó un amplio "movimiento social", concedieron a la historia moderna hondureña legados sociales o políticos que los estudiosos han marginado y que deben integrarse a la evaluación de la ruptura que representa el golpe de Estado del 2009.

En la historiografía disponible sobre la transición a la democracia en Honduras, durante las últimas dos a tres décadas, existe un vacío sobre la particularidad más importante de la estructura económica de Honduras a fines del siglo XX: el dominio de inmigrantes árabe-palestinos en la estructura comercio-industrial $y$, en menor escala, el aporte de ciertas familias de ascendencia judía, familias lideradas por el clan Rosenthal (Pastor Fasquelle, 2018).

En 1989 fue electo presidente Rafael Leonardo Callejas (1990-1994), destacado miembro del Partido Nacional de Honduras y emparentado con varios fundadores de dicho partido desde su organización formal a fines de la segunda década del siglo XX. Según Marta Elena Casaus Arzú, una tendencia generalizada en el istmo en aquella época: el retorno al poder de las tradicionales oligarquías mediante una metamorfosis económica y social, aun cuando estas se enfrentaban a un amplio reto político contra su antigua hegemonía en el poder, a raíz de los conflictos armados en la región durante las décadas de 1970 y 1980. De hecho, según Casaus Arzú, Callejas representaba un tipo de "intelectual orgánico", portavoz de un nuevo proyecto político neoliberal y de una "nueva derecha" que reflejaba, a nivel centroamericano, la "recomposición del bloque dominante" de la estructura socioeconómica regional.

Según un informe biográfico del Departamento de Estado de los EE. UU., Callejas nació en 1943 en el seno de una rica familia hacendada. Durante los gobiernos militares de la década de 1970, Callejas fungió como subsecretario y también secretario del Ministerio de Recursos Naturales. Este llegó a la presidencia de Honduras con una licenciatura y una maestría en economía agrícola de la Mississippi State University, proceso educativo que sin duda afianzó su fácil manejo del inglés, poniendo en práctica los conocimientos adquiridos no solo en la universidad, sino también en el Instituto de Ciencias Sociales de La Haya y en la FAO de Roma.

Según, Casaus Arzú, el proceso en el cual Callejas supuestamente se convirtió en "intelectual orgánico" de una restructurada "oligarquía hondureña" se fundamentó en la supervivencia de "antiguas redes familiares que detentan el poder desde la época colonial (Casaus Arzú 268). A diferencia de mucha de la literatura generada durante la última década sobre la transición a la democracia en Honduras, Casaus Arzú representa un esfuerzo de cierta manera tradicional en las ciencias sociales: explorar la relación entre estructura socioeconómica y sistemas políticos y gobiernos. La validez de esta hipótesis aplicada para el caso hondureño es el problema fundamental que se escudriña ahora.

En 1990, Mario Flores G. presentó una muy innovadora tesis en torno a las clases dominantes del capitalismo de Honduras. Al margen de los importantes trabajos de Antonio Murga Frassinetti, cuyas hipótesis Flores cuestionaba, hasta esta época 
se había investigado poco sobre el tema y seguimos igual si lo apreciamos desde la historiografía, tal como lo señalamos en las conclusiones más adelante. Sea como sea, según Flores, a partir de la década de 1960, impulsada por una nueva industrialización, surgió en Honduras una burguesía nacional cuyos rasgos básicos se caracterizan mejor por razón de la categoría de un "capital financiero", a la vez producto de la concentración de capital y la unificación de "todas las formas parciales del capital".

Este capital financiero a su vez se distribuía en 26 grandes grupos económicos organizados en más de 2000 empresas. En su conjunto, 25 de estos grupos económicos constituía la "burguesía nacional", eje fundamental y mayoritario del total del capital financiero, puesto que solamente los primeros tres grupos (SOGERIN, Inversiones Facusse, S.A. e Inversiones Continental) representan más capital que aquel registrado por las empresas transnacionales (Cuadro 1). Igualmente, señala Flores, un subgrupo de empresas, incluyendo esta vez al grupo transnacional, formaban una "oligarquía financiera" dentro del capital financiero en sí. 
Cuadro 1

GRUPOS ECONÓMICOS MÁS IMPORTANTES DE HONDURAS, DÉCADA DE 1980 (PORCENTAJE DEL CAPITAL FINANCIERO DEL PAÍS)

\begin{tabular}{|c|c|}
\hline Grupo Económico & Porcentaje \\
\hline Transnacionales & 22.51 \\
\hline SOGERIN & 9.82 \\
\hline Inversiones Facussé, S. A. & 8.27 \\
\hline Inversiones Continental & 6.29 \\
\hline BANCATLAN, S. A. & 5.00 \\
\hline Grupo Goldstein & 4.49 \\
\hline Inversiones Andonie Fernández & 3.94 \\
\hline Inversiones Williams & 3.70 \\
\hline El Ahorro Hondureño, S. A. & 3.60 \\
\hline Inversiones Honduras, S. A. & 2.98 \\
\hline Inversiones Bendeck, S. A. & 2.90 \\
\hline Inversiones Fasquelle & 2.69 \\
\hline Inversiones Kafati, S. A. & 2.58 \\
\hline Inversiones Kattan & 2.57 \\
\hline Intereses Militares & 2.18 \\
\hline Inversiones Bamer, S. A. & 2.13 \\
\hline Inversiones Larach, S. A. & 1.94 \\
\hline Inversiones Canahuati & 1.88 \\
\hline Inversiones Maduro & 1.68 \\
\hline Grupo Hasbun & 1.60 \\
\hline Inversiones Flores Rodil & 0.94 \\
\hline Inversiones Callejas & 0.79 \\
\hline Inversiones Occidente & 0.61 \\
\hline Inversiones Sikafy & 0.58 \\
\hline Inversiones Handal, S. A. & 0.15 \\
\hline Inversiones Kafie & 0.06 \\
\hline Otros & 1.84 \\
\hline Empresas sin vínculos a Grupos & 2.54 \\
\hline
\end{tabular}

Fuente: Elaboración propia a partir de Flores. 
Por último, Flores también postuló que los 25 grupos económicos nacionales, los que constituían el 60 por ciento del capital social del país, representaban una "oligarquía financiera nacional", es decir, "un grupo capitalista nacional dominante y oligárquico que controla monopólicamente, junto con el capital extranjero, la mayor parte de la actividad económica, política y cultural del país" (76).

Por lo tanto, Inversiones Callejas, designado como el grupo económico número 22 dentro del Cuadro 1, forma parte de la "oligarquía financiera nacional". ¿Constituyó, entonces, el advenimiento al poder de Rafael Leonardo Callejas en 1990 el ascenso de un "intelectual orgánico" de la "oligarquía financiera nacional" establecida a partir de 1960, pero entroncada en "antiguas redes familiares que detentan el poder desde la época colonial"? Superficialmente pareciera que sí, puesto que la historiografía existente registra antecedentes al menos del apellido Callejas en Honduras ya para fines del siglo XVIII. No obstante, si Rafael Leonardo Callejas procede de antiguas familias coloniales, estas no formaron parte de las familias pudientes y dominantes de la época colonial y poscolonial.

Por su parte, el Cuadro 1 registra otra variable más importante en esta consideración de la configuración histórica de las élites económicas de Honduras: la presencia de árabe-hondureños entre las élites económicas de Honduras. Un rápido repaso del Cuadro 1 muestra la abrumadora presencia de las familias de descendencia árabe, particularmente palestinas. Sin embargo, es también importante ver la posición de ciertas familias judío-hondureñas, es decir, los Goldstein, y los Rosenthal Oliva, liderado por el ahora difunto Jaime; estos últimos propietarios de Inversiones Continental.

Se destacan personajes de las familias judío-hondureñas, Jaime Rosenthal Oliva y Gilberto Goldstein Rubinstein, porque desempeñaban papeles sumamente importantes en las cúpulas de los partidos tradicionales. Rosenthal Oliva se destacó desde de las décadas de 1960 en las filas del Partido Liberal. Fue solo uno de dos parlamentarios judíos electos para la malograda legislatura de 1971 a 1976. En 1971, fundó el diario El Tiempo en San Pedro Sula a raíz de las disputas con La Prensa y su propietario, Jorge J. Larach de ascendencia árabe-palestino. Por su parte, Goldstein Rubinstein está íntimamente vinculado con el Partido Nacional y fue secretario privado del presidente Callejas entre 1990 y 1994. En el anterior período de gobierno, junto con Rosenthal Oliva, Goldstein Rubinstein fue uno de los dos diputados judío-hondureños en el Congreso Nacional. Lamentablemente, para muchos, sus enemigos dentro del gobierno del presidente Juan Orlando Hernández utilizaron los errores de negociaciones con narcotraficantes del hijo de Jaime Rosenthal -Yani Rosenthal- para desarticular una de las fortunas más importantes no solo de Honduras, sino de Centroamérica (Jiménez 2014 y Moreno). ${ }^{2}$

En relación con los árabe-hondureños, el Cuadro 2 presenta los once grupos económicos que fácilmente pueden identificarse como familias cuyas generaciones no se remontan más allá de las primeras décadas del siglo XX, es decir, aquellos con apellidos Facusse, Andonie, Bendeck, Kafati, Catan, Larach, Canahuati, Hasbun y Sikafie. 


\begin{tabular}{lc}
\hline Grupo económico & Porcentajes \\
\hline 1. Inversiones Facussé & 8.27 \\
2. Inversiones Andonie Fernández & 3.94 \\
3. Inversiones Bendeck, S. A. & 2.90 \\
4. Inversiones Kafati, S. A. & 2.58 \\
5. Inversiones Kattán & 2.57 \\
6. Inversiones Larach, S. A. & 1.94 \\
7. Inversiones Canahuati & 1.88 \\
8. Grupo Hasbun & 1.60 \\
9. Inversiones Sikafy & 0.58 \\
10. Inversiones Handal, S. A. & 0.15 \\
11. Inversiones Kafie & 0.06 \\
Total & 26.47 \\
\hline
\end{tabular}

Fuente: Elaboración propia a partir de Flores.

Todos estos, por supuesto, son apellidos recientes en la larga historia de Honduras. Es más, apellidos árabe-hondureños considerados claves en el golpe de Estado e importantes en la "nueva derecha" capitalista hondureña, por muchos analistas y en la prensa popular de izquierda, Kafie, Nasser y Atala, por ejemplo, no aparecen en la década de 1980 como importantes capitalistas en Honduras. El ensanchamiento económico capitalista de los Nasser y Atala y los Kafie es más bien un fenómeno de la década de 1990 y la primera década del siglo actual, aunque el matrimonio Nasser-Facusse permite trazar alianzas matrimoniales en los más altos niveles de esta burguesía que merecen estudiarse más a fondo.

Los datos que arroja el Cuadro 1, juntamente con el Cuadro 2, ofrecen una documentación más amplia para cuestionar la tesis de recomposición de la oligarquía hondureña colonial y su relación con la transición a la democracia en la década de 1980 postulada por Casaus Arzú. En primer lugar, la información que proporcionó Mario Flores señala que, para la década de 1980, un poco más de un cuarto del capital 
financiero del país (el más importante dentro del capitalismo hondureño de esa época) estaba en manos de familias cuyos orígenes se remontaban a una inmigración que tuvo lugar solamente a partir de la última década del siglo XIX y sobre todo durante la primera década del siglo XX. En segundo lugar, las primeras generaciones de esta inmigración, en general, se negaban a formar alianzas matrimoniales con la elite hondureña. Esta, a su vez, también las rechazaba, por lo menos durante las primeras cinco décadas del siglo $X X$, con algunas excepciones. Un estudio más reciente muestra que durante las últimas dos o tres décadas esa endogamia etnoracial está desapareciendo, especialmente entre los hondureños de ascendencia árabe-palestina.

¿Presenciábamos, entonces, con el ascenso de Callejas, a un "intelectual orgánico" de la "oligarquía” colonial? Si lo fue, ¿cómo caracterizamos la presidencia de Roberto Suazo Córdova en el contexto histórico de relaciones entre estructuras sociales, grupos económicos y el sistema político de Honduras en el siglo XX?

Resumamos primero nuestras apreciaciones sobre el advenimiento a la presidencia de Rafael Leonardo Callejas Romero. Callejas Romero no parece haber sido un "intelectual orgánico" portavoz de una oligarquía hondureña con arraigo colonial. El poderío económico de los Callejas durante la década de 1980 es probable que no se remontara más allá de las últimas décadas del siglo XIX o las primeras décadas del siglo XX. De hecho, la historiografía suele indicar que las poderosas familias coloniales, aquellas destacadas en los escritos de Leticia Oyuela, Mario F. Martínez Castillo, Luis Pedro Taracena Arriola, y más recientemente por Ismael Zepeda y Libny R. Ventura Lara, no lograron reproducir su poderío económico durante la transición al siglo XIX y al siglo XX. No obstante, sí parece ser que durante el siglo XIX las viejas familias coloniales se constituyeron en una "oligarquía terrateniente-minera" en los alrededores de Tegucigalpa, según las investigaciones de Oscar Zelaya, otro historiador de Honduras que ha abordado el tema con fundamento archivístico de primera mano (Zelaya 1992).

Ahora bien, durante la transición al siglo XX, con el nuevo ciclo minero en el sur y en los alrededores de Tegucigalpa, junto con el ascenso de la economía bananera en la Costa Norte, la vieja "oligarquía terrateniente-minera" no solo perdió su hegemonía sobre el poder político dentro de la Alcaldía de Tegucigalpa, sino que también fue incapaz de contrarrestar el predominio del capital extranjero y así aprovechar la acumulación comercial e industrial de la época. Es más, parece que fue la acumulación capitalista en San Pedro Sula la que más aprovechó los nuevos ciclos con vínculos a la economía mundial.

Las antiguas familias de Tegucigalpa y sus alrededores nunca pudieron sostener una hegemonía política sobre el Estado moderno, incluso personajes tan prominentes como el presidente Policarpo Bonilla (1858-1926). Este terminó su vida como asesor legal de Samuel Zemurray en Nueva Orleans, como lo registra con lujo de detalle su archivo personal que yace en el Archivo Nacional de Honduras en Tegucigalpa (Euraque 2018). De hecho, fue un caudillismo ultramontano, representado 
por los dos partidos tradicionales, los que monopolizaron el poder de la Alcaldía de Tegucigalpa y también dentro del Estado nacional. El movimiento de la huelga de capitales de 1968 representó un esfuerzo por cuestionar ese sistema; de esa manera, también puede caracterizarse el golpe de 1972, contrario a lo sucedido en 1963 cuando el General López Arellano, con apoyo del Partido Nacional, derrocó el presidente Ramón Villeda Morales.

A diferencia del golpe de 1963 y el golpe del 2009, la intervención miliar de 1972 no produjo un derramamiento de sangre, estado de sitio, toques de queda, exiliados o encarcelamientos. En su lugar recibió amplio apoyo de sectores organizados de la clase trabajadora y campesina, grupos que habían sido blancos de la represión en 1963. De hecho, más que una alianza institucional entre el ejército y un partido político, a partir de 1972 el nuevo régimen lanzó inmediatamente un ataque directo contra los partidos tradicionales.

El decreto número 3 del 6 de diciembre de 1972 momentáneamente destruyó la principal fuente de ingresos y lealtades de los caudillos de ambos partidos, al declarar ilegales las "contribuciones voluntarias" de empleados estatales a los partidos políticos. Los caudillos habían institucionalizado estas así llamadas contribuciones como medio de reclutamiento y para garantizarse fidelidades. Si bien la transición a la democracia trajo consigo nuevamente esta forma de financiar los partidos políticos, la metamorfosis económica de los grupos económicos de fines del siglo XX registraba otras intervenciones en el sistema político. Este hecho comenzó verdaderamente con la presidencia de Suazo Córdova, especialmente por medio del papel de la familia Facusse en ese gobierno, cuando Carlos Flores Facusse se desempeñó como secretario privado del presidente Suazo Córdova.

Ese hecho registraba otro hecho socioeconómico que hemos contrapuesto ante la tesis de Marta Elena Casaus Arzú: que la mayoría de los nuevos espacios comerciales e industriales del siglo XX los ocuparon, primero, alemanes, y en menor escala otros extranjeros europeos; $\mathrm{y}$, segundo, los inmigrantes árabe-palestinos. Los alemanes estrecharon relaciones y parentesco con familias hondureñas, pero el General Tiburcio Carías Andino (1933-1948), durante la Segunda Guerra mundial, presionado por el gobierno norteamericano, intervino los negocios alemanes y la persecución posterior le restó status social y político a la vieja y poderosa colonia alemana, lo cual por supuesto afianzó el poderío económico norteamericano.

Por su parte, las primeras generaciones árabe-palestinas se mantuvieron al margen de la vida social y política del país. No obstante, a partir de 1950, los árabepalestinos lentamente estrecharon relaciones matrimoniales de viejos y nuevos ricos y adquirieron, poco a poco, la ciudadanía hondureña. Por lo tanto, si hubo metamorfosis en la oligarquía de Honduras, el proceso no se dio en la década de 1980; el proceso se inició durante la transición al siglo XX, en el marco general de la nueva integración de la economía hondureña al mercado mundial mediante la plata y el 
banano posteriormente, por medio de cierta industrialización que tuvo más éxito en San Pedro Sula como eje de la economía de la Costa Norte.

Más importante aún, la metamorfosis fue tal que ni los Callejas ni otras familias con mucho más abolengo colonial detentaban en la década de 1990 el poder económico en Honduras. Para ese entonces, eran los descendientes de las familias árabepalestinas, ahora hondureñas en su sentido legal, las familias élites con más poderío económico en el país, aunque no todas. De nuevo, la importancia de la familia Flores Facusse en la presidencia de Suazo Córdova y la presidencia propia de Carlos Flores Facusse, entre 1998 y 2002, evidenció esa nueva realidad de la estructura social de Honduras y la nueva democracia que comenzó en la década de 1980 y que se violentó en el 2009. De hecho, hoy en día Rafael Leonardo Callejas se encuentra apresado en los EE. UU., luego de declararse culpable en una corte de Nueva York ante una acusación de haber recibido sobornos millonarios de parte de funcionarios de la FIFA mientras Callejas fungió como presidente de la Federación de Fútbol de Honduras (Ruíz).

\section{Conclusiones}

Actualmente, las "élites", “oligarquías" y "burguesías” en Honduras aún carecen de estudios históricos sistemáticos fundamentados en archivos públicos y privados. En este vacío historiográfico es difícil caracterizar el accionar y motivación de las supuestas "10 familias" que supuestamente financiaron el golpe de Estado del 2009, aunque aun así continúan publicaciones con superficiales referencias a "la oligarquía hondureña" (Shipley). Tampoco es fácil determinar claramente el accionar de las élites en sí en su conjunto, en sus segmentos, fracciones y personajes más conspicuos, ante la disyuntiva que presenta la ilegitimidad que sufre el sistema político hondureño, y los partidos políticos, sobre todo con el hecho de que durante la década posterior al golpe de Estado parece ser que el peso de los segmentos tradicionales más poderosos y su influencia sobre el Estado concesionario lo asumieron más bien clanes de narcotraficantes transnacionales, quienes invirtieron en los mecanismos políticos partidarios clientelistas de antaño (Chayes).

Durante los últimos cinco años, esta situación ha llevado a los pensadores de la política exterior estadounidense a comprometerse en Honduras con un proyecto de extradición que hasta ahora no solo involucra a la Administración para el Control de Drogas (DEA, por sus siglas en inglés) en la extradición de capos del narcotráfico hondureño, sino que también prominentes personajes de las élites tradicionales del país, incluyendo, además del hermano del actual presidente de Honduras, también a un hijo del presidente anterior, Pepe Lobo (2010-2014). Es más, ya con su hijo Yani encarcelado en los EE. UU., la muerte reciente de Jaime Rosenthal, La muerte de Rosenthal, a comienzos del 2019, significo el cierre y final de ese ciclo progresista de la burguesía sampedrana (Torres Calderón). 
Sea como sea, la noción del accionar de las llamadas "10 familias" comenzó a solidificarse desde comienzos de agosto del 2009, cuando el propio presidente Zelaya denunció en México, en declaraciones que también circularon por el internet por toda América Latina, ante el riesgo de ser asesinado, "anunció la existencia de un documento, que mantiene resguardado en un lugar secreto, en el cual ha identificado a 10 familias 'con nombre propio, responsables del golpe', el cual se revelaría en caso de 'cualquier cosa que me pase, si yo fuera sacrificado'" (Albarrán). El hecho es que lo que más distingue la configuración histórica de las élites en Honduras no es una "oligarquía" de "10 familias", ni sus orígenes en la agroexportación bananera, ni sus transformaciones durante los últimos 20 años, sino más bien lo que distingue es su dimensión etnoracial árabe-palestina, y libanés en menos escala. Interesa en particular la historia de la relación de esta etnohistoria en su dinámica con la historia del sistema político de Honduras, sus implicaciones para el sistema político durante las últimas tres décadas y el carácter de las llamadas "élites económicas" en la segunda década del siglo actual, luego del golpe de Estado de junio del 2009. La posibilidad de la Alianza entre Salvador Nasralla Salum y Manuel Zelaya Rosales en las elecciones de noviembre de 2017 debe analizarse e investigarse en el contexto histórico esbozado en este artículo.

\section{Notas}

1 El papel de Samuel Zemurray en la cultura capitalista de la Costa Norte de Honduras, sobre todo en San Pedro Sula, en particular sus legados históricos, aun está por investigarse. Actualmente, el autor escribe una biografía de un finquero hondureño, Rafael López Padilla, que será una ventana a ese mundo. Existe, sin embargo, una aproximación preliminar por Pastor Fasquelle (2002).

2 El comunicado oficial relacionado con la captura de Tony Hernández en noviembre del 2018 se encuentra en https://www.dea.gov/press-releases/2018/11/26/dea-announces-arrest-formerhondurancongressman-and-brother-current

\section{Bibliografía}

Albarrán, Gerardo. (6 de agosto de 2019). Las diez familias. Página 12. Recuperado de https:// www.pagina12.com.ar/diario/elmundo/subnotas/4-41650-2009-08-06.html

Barahona, Marvin. Evolución histórica de la identidad nacional. Tegucigalpa: Editorial Guaymuras, 1991.

Bull, Benedicte. Honduras: Privatization in the Ritual Aid Dance. Aid, Power, and Privatization: The Politics of Telecommunications Reform in Central America. Cheltenham, UK: Elgar Publishing, 2005. 136-137.

Casaus Arzú, Marta Elena. La Metamorfosis De las Oligarquías Centroamericanas. Centroamérica: Balance de la Década de los 80. M. Casaus Arzú y R. Castillo Quintana, Coords. Madrid. Fundación CEDEAL 1993. 59-83.

Cohen, Richard. The Fish that Ate the Whale: The Life and Times of America's Banana King. New York: Picador, 2013. 
Consejo Hondureño de la Empresa Privada. Documento de Posición. 19 de agosto, 2009. Recuperado de http://www.cohep.com/pdf/Documento\%20Juridico\%20COHEP\%20 19\%20Agosto\%202009.pdf

Chayes, Sarah. When Corruption is the Operating System: The Case of Honduras. Washington: Carnegie Endowment for International Peace, 2017.

Crosby, Benjamin. Crisis y Fragmentación: Relaciones Entre Los Sectores Público- Privado en América Central. Occasional Paper Series, 10(1985): 21-26.

Comisión de la Verdad y Reconciliación. El informe de la Comisión oficial para esclarecer los antecedentes del Golpe del 2009 es muy distinto. Ver, Comisión de la Verdad y Reconciliación, Informe de la Comisión de la Verdad y la Reconciliación (CVR) sobre el Golpe de Estado acaecido en Honduras el 28 de junio del 2009. Tegucigalpa: Congreso Nacional de Honduras, 2011.

Comisión de Verdad, Informe de la Comisión de Verdad: Sin verdad no hay Justicia. Recuperado de http://comisiondeverdadhonduras.org/sites/default/files/Informe $\% 20$ COMISION\%20DE\%20VERDAD\%20.pdf

Discua, Allan et al. Las Grandes Empresas Familiares de Honduras: La Influencia del Estado y la inmigración del siglo XX. Familias Empresarias y grandes empresas familiares en América Latina y España, Una Visión de Largo Plazo. P. Fernández Pérez y A. Luch, Eds. Bilbao: Fundación BBVA, 2015. 319-343.

Euraque, Darío A. Edmond L. Bogran. EnCaribe Enciclopedia del Caribe, Historia y Cultura. Recuperado de http://www.encaribe.org/es/article/edmond-l.-bogran/563

Euraque, Darío A. Social Structure and the Emergence of the Press in Honduras: A Historical Perspective. Tesis de maestría, University of Wisconsin-Madison, 1986.

Euraque, Darío A. “La 'Reforma Liberal' en Honduras y la Hipótesis de la 'Oligarquía Ausente': 1870s-1930s". Revista de Historia, 23(1991): 7-56.

Euraque, Darío A. Estructura Económica, Formación de Capital Industrial, Relaciones Familiares y Poder Político en San Pedro Sula: 1870s-1958. Revista Polémica, 18(1992): 31-50.

Euraque, Darío A. San Pedro Sula, Actual Capital Industrial de Honduras: Su Trayectoria entre Villorrio Colonial y Emporio Bananero, 1536-1936. Mesoamérica (Vermont-Guatemala), 26(1993): 217-252.

Euraque, Darío A. La Metamorfosis de una Oligarquía y las Elites de Poder en la Década de 1980: el Caso de Honduras. Elites, Empresarios y Estado en Centroamérica, Marta Elena Casaus Arzú, edit. Madrid: Fundación CEDEAL, 1996a. 59-83.

Euraque, Darío A. Movimientos Populares, como racismo y la Problemática de la Identidad Nacional. Paraninfo, 10(1996b): 1-14.

Euraque, Darío A. Reinterpreting the Banana Republic: Region and State in Honduras, 1870-1972. Chapel Hill: University of North Carolina Press, 1996.

Euraque, Darío A. El capitalismo de San Pedro Sula y la historia política hondureña, 1870-1972 Tegucigalpa: Editorial Guaymuras, 1997.

Euraque, Darío A. Conversaciones Históricas con el Mestizaje en Honduras y su Identidad Nacional. San Pedro Sula: Centro Editorial, 2004.

Euraque, Darío A. Estructura Social, Historia Política y la Nueva Democracia en Honduras. Politica y Desarrollo en Honduras, 2006-2009: Los Escenarios Posibles. D. Achard y L. E. González, Eds. Tegucigalpa: PNUD, 2006. 259-285.

Euraque, Darío A. Historiografía de Honduras. Tegucigalpa: Instituto Hondureño de Antropología e Historia, 2009. 
Euraque, Darío A. Los árabes de Honduras: entre la inmigración, la acumulación y la política. Contribuciones árabes a las identidades iberoamericanas, Karim Hauser y Daniel Gil, Eds. Madrid: Casa Árabe-IEAM, 2009a. 233-284.

Euraque, Darío A. La Modernidad de Honduras ante la Sociología Histórica, 1950-2000. XIII Congreso de la Asociación Centroamericana de Sociología, 27 al 31 de agosto de 2012, Facultad de Ciencias Sociales, Universidad Nacional Autónoma de Honduras, Tegucigalpa, Honduras.

Euraque, Darío A. Policarpo Bonilla (1858-1926) luego de ejercer la presidencia de Honduras ¿Se convirtió el Dr. Bonilla en el principal abanderado del capitalismo bananero norteamericano en su época? Ponencia, XIV Congreso Centroamericano de Historia, Guatemala, 6-10 de agosto 2018.

Flores Valeriano, Enrique. La Explotación Bananera en Honduras: Capítulos del Deshonor Nacional Tegucigalpa: Editorial Universitaria, 1979.

Frank, Dana. The Long Honduran Night: Resistance, Terror, and the United States in the Aftermath of the Coup. Boston: Haymarket Square Books, 2018.

Frewen, Cordelia. Las Paredes Hablan Cuando los Medios Callan: Grafiti \& memoria histórica en Honduras pos-golpe. Final Project, SOWK 570, University of British Columbia, Canadá, Departamento de Museología Antropológica, 30 abril 2014.

Guevara-Escudero, José Francisco. 19th Century Honduras: A Regional Approach to the Economic History of Central America, 1839-1914 (tesis doctoral). New York University, 1983.

Indiano, César. Los hijos del infortunio: Historia de un país, al revés. Tegucigalpa: Litografía López, 2009.

Indiano, César. Los Oligarcas ¿De dónde salieron los ricos? Tegucigalpa: ZAFRA Editores, 2014.

Jackson, Jeffrey T. The Globalizers: Development Workers [in Honduras]. Baltimore: John Hopkins University Press, 2005.

Jiménez, Ismael et al. “Los 12 millonarios más importantes de Centroamérica”. Forbes, diciembre 27, 2014.

Lara, Libby R. Ventura. El linaje de la Lara Honduras: Conquistadores, encomenderos y hacendados. Tegucigalpa: Instituto Hondureño de Antropología e Historia, 2009.

León, Andrés. Rebellion under the Palm Trees: Memory, Agrarian Reform and Labor in the Aguán, Honduras (tesis doctoral). City University of New York, 2015.

León, Andrés y Marc Edelman. Ciclos de acaparamiento de Tierras en Centroamérica: Un Argumento a favor de historizar y un Estudio de Caso sobre el Bajo Aguan, Honduras. Anuario de Estudios Centroamericanos, 40(2014): 195-228.

Leonard, Thomas L. The United States and Central America. Mobile: University of Alabama Press, 1984.

Márquez, Javier, et al. Estudio Sobre la Economía de Honduras. Tegucigalpa: Banco Central de Honduras, 1951.

Mahoney, James. The Legacies of Liberalism: Path Dependence and Political Regimes in Central America. Baltimore: John Hopkins University Press, 2001.

Martínez, Juan Ramón. Itinerario de una Caída: Las recomendaciones que no escuchó Zelaya Tegucigalpa: Ediciones 18 Conejo, 2009.

Martínez, Juan Ramón. Diario del Retorno: Lo ocurrido en Honduras, a partir del 28 de junio del 2009. Tegucigalpa: Ediciones 18 Conejo, 2010.

Meza, Víctor et al. Golpe de Estado: Partidos, instituciones y cultura política. Tegucigalpa: CEDOH, 2010. 
Meza, Víctor. Golpe de Elites. Recuperado de http://www.cedoh.org/documentacion/articulos/ files/EL\%20GOLPE\%20DE\%20LAS\%20ELITES.pdf

Meza, Víctor et al. Honduras: Poderes Facticos y Sistema Político. Tegucigalpa: CEDOH, 2007.

Moreno, S. J., Ismael. Ascenso y Caída del Clan de los Rosenthal. Revista Envío, 404 (2015). Recuperado de http://www.envio.org.ni/articulo/5107

Newson, Linda A. Silver Mining In Colonial Honduras. Revista de Historia de América, 97(1984): $45-76$.

Norwsworthy, Kent y Tom Barry. Ethnic Groups and Native People. Inside Honduras. Albuquerque, N. M.: Inter-Hemispheric Education Resource Center, 1993. 127- 131.

Pastor Fasquelle, Rodolfo. "Roberto Fasquelle Orellana, su cuento", manuscrito inédito, 2019.

Pastor Fasquelle, Rodolfo. Sam El Guineyero y la Cultura Empresarial. Primera Parte, Revista Umbrales, 16(2002): 1-4.

Pastor Fasquelle, Rodolfo. Sam El Guineyero y la Cultura Empresarial. Segunda Parte, Revista Umbrales, 17(2002): 1-4.

Robinson, William I. Transnational Conflicts: Central America, Social Change and Globalization. London: Verso, 2003.

Seppänen, Maaria. Transforming the Concessional State? The Politics of Honduras' Poverty Reduction Strategy. Institute of Development Studies, University of Helsinki, 2002.

Sosa, Eugenio. Transformaciones en las Elites económicas, Estado y el Proceso de Democratización: El Caso de Honduras, 1990-2017. Anuario de Estudios Centroamericanos, 43(2017): 125-148.

Romero, Ramón. Los grupos generadores de electricidad y el poder político. Honduras: Poderes Facticos y Sistema Político. V. Meza et al. Tegucigalpa: CEDOH, 2007.

Ruiz, R. Former Head of Honduran Federation Pleads Guilty in FIFA Case. New York Times, March 28, 2016.

Shipley, Tyler. Ottawa and empire: Canada and the military coup in Honduras. Toronto: Between the Lines, 2018.

Torres Calderón, Manuel. Dos lápidas para Rosenthal. Proceso Digital, 3 marzo 2019. Recuperado de http://www.proceso.hn/criterios1/29-criterios-proceso/dos-lapidaspara-rosenthal.html

Torres-Rivas, Edelberto. Repression and Resistance: The Struggle for Democracy in Central America. Boulder: Westview Press, 1989.

Velásquez Rivera, Édgar. El Golpe de Estado en Honduras. Bogotá: Ediciones Artrópodos, 2010.

Villacorta, Carmen Elena y Esteban De Gori, Eds. Golpe Electoral y Crisis Politica en Honduras. Ciudad Autónoma de Buenos Aires: CLACSO, 2018.

Zelaya, Oscar. Tipificación del Grupo Social Dominante en el Antiguo Departamento de Tegucigalpa, 18391875 (tesis de licenciatura). Universidad Nacional Autónoma de Honduras, 1992.

Zepeda, Ismael. La familia Midence: Una historia vigente. Aproximación a su genealogía Tegucigalpa: Lithopress, 2005.

Darío A. Euraque. Hondureño. Profesor catedrático en Trinity College en Hartford, Connecticut, EE. UU. Doctor en la historia de América Latina y el Caribe en la Universidad de Wisconsin- Madison. Sus primeras publicaciones ahondaron sobre 
la historia económica y social de Honduras: El Capitalismo de San Pedro Sula y la Historia Política Hondureña, 1870-1972. Luego, Estado, Poder, Nacionalidad y Raza en la Historia de Honduras: Ensayos y Conversaciones Históricas con el Mestizaje en Honduras y su Identidad Nacional. También ha publicado reflexiones sobre la historiografía de Honduras en el siglo XX: Historiografía de Honduras. Fungió como Gerente del Instituto Hondureño de Antropología e Historia entre el 2006 y 2009, sobre esa experiencia publicó un testimonio: El golpe de Estado del 28 de junio del 2009, el Patrimonio Cultural y la Identidad Nacional de Honduras. Con Yesenia Martínez García publicó, La Diáspora Africana en los programas educativos de Centroamérica.

Contacto: dario.euraque@trincoll.edu

ORCID: 0000-0002-0140-159X 